\title{
Individual factors increasing complexity of drug treatment-a narrative review
}

\author{
Steffen J. Schmidt ${ }^{1}$ - Viktoria S. Wurmbach ${ }^{2,3} \cdot$ Anette Lampert ${ }^{2,3} \cdot$ Simone Bernard ${ }^{1} \cdot$ HIOPP-6 Consortium • \\ Walter E. Haefeli ${ }^{2,3} \cdot$ Hanna M. Seidling ${ }^{2,3} \cdot$ Petra A. Thürmann ${ }^{1,4}$
}

Received: 16 April 2019 / Accepted: 8 December 2019/Published online: 1 April 2020

(C) The Author(s) 2020

\begin{abstract}
Purpose Complexity of drug treatment is known to be a risk factor for administration errors and nonadherence promoting higher healthcare costs, hospital admissions and increased mortality. Number of drugs and dose frequency are parameters often used to assess complexity related to the medication regimen. However, factors resulting from complex processes of care or arising from patient characteristics are only sporadically analyzed. Hence, the objective of this review is to give a comprehensive overview of relevant, patient-centered factors influencing complexity of drug treatment.

Methods A purposeful literature search was performed in MEDLINE to identify potential complexity factors relating to the prescribed drug (i.e. dosage forms or other product characteristics), the specific medication regimen (i.e. dosage schemes or additional instructions), specific patient characteristics and process characteristics. Factors were included if they were associated to administration errors, nonadherence and related adverse drug events detected in community dwelling adult patients.

Results Ninety-one influencing factors were identified: fourteen in "dosage forms", five in "product characteristics", twelve in "dosage schemes", nine in "additional instructions", thirty-one in "patient characteristics" and twenty in "process characteristics". Conclusions Although the findings are limited by the non-systematic search process and the heterogeneous results, the search shows the influence of many factors on the complexity of drug treatment. However, to evaluate their relevance for individual patients, prospective studies are necessary.
\end{abstract}

Keywords Drug treatment $\cdot$ Administration error $\cdot$ Nonadherence $\cdot$ Narrative review $\cdot$ Complexity factor $\cdot$ Patient-centered

Steffen J. Schmidt and Viktoria S. Wurmbach contributed equally to the work.

Electronic supplementary material The online version of this article (https://doi.org/10.1007/s00228-019-02818-7) contains supplementary material, which is available to authorized users.

Hanna M. Seidling

hanna.seidling@med.uni-heidelberg.de

1 Department of Clinical Pharmacology, School of Medicine, Faculty of Health, Witten/Herdecke University, Alfred-Herrhausen-Straße 50, 58448 Witten, Germany

2 Department of Clinical Pharmacology and Pharmacoepidemiology, University of Heidelberg, Im Neuenheimer Feld 410, 69120 Heidelberg, Germany

3 Cooperation Unit Clinical Pharmacy, University of Heidelberg, Im Neuenheimer Feld 410, 69120 Heidelberg, Germany

4 Philipp Klee-Institute for Clinical Pharmacology, HELIOS Clinic Wuppertal, Heusnerstraße 40, 42283 Wuppertal, Germany

\section{Introduction}

A general definition of complexity of drug treatment is missing so far. Previous studies typically focus on the medication regimen, and, thus, mostly consider the number of drugs and the frequency of administration $[1,2]$.

The most popular tool to quantify complexity is the Medication Regimen Complexity Index (MRCI). This score is based on literature and interdisciplinary expert opinions and considers 65 aspects of medication regimen complexity that are related to the dosage form, the dosage scheme or additional instructions for the application [3, 4]. It was already shown that medication regimen complexity causes administration errors and (non-)intentional nonadherence $[3,5,6]$ with known consequences such as higher costs [7], increased hospital admissions [7] and mortality [8]. However, medication regimen complexity is only one part of complexity of drug treatment, as it does not only depend on the medication regimen but also on other factors such as demographic and clinical factors $[4$, 
9]. The total number of drugs, especially polypharmacyusually defined as the simultaneously use of five or more drugs [10] - automatically influences the number of factors increasing complexity of drug treatment. This emphasizes the relevance of complexity to the individual patient: in older adults, at least one in three patients is affected by polypharmacy, making this issue highly relevant to a majority of patients [11, 12]. Other risk factors at the patient level are, for example, impaired dexterity [13] and hospitalization [14]. Yet, such factors of complexity of drug treatment are only presented selectively $[9,15,16]$ and, in general, none of the most commonly used tools assessing complexity addresses these patient-relevant aspects of complexity [17].

When taking the patients' perspective, a broader concept of complexity than the commonly used medication regimen complexity is needed. This work therefore aims to give a comprehensive and theory-driven overview of relevant, patient-centered factors influencing complexity of drug treatment.

\section{Method}

An undirected inductive literature search was conducted in MEDLINE via Pubmed by the authors VSW and SJS to identify factors potentially increasing complexity of drug treatment. This was based on the already known consequences of complexity, i.e. administration errors and nonadherence and therefore the search terms used were "adherence", "administration error", "administration errors", "complex*", "compliance", "medication adherence [MeSH]", "medication errors [MeSH]", "nonadherence", "non adherence", "non compliance", "noncompliance", "nonpersistence", "non persistence", "patient compliance [MeSH]", "persistence", "treatment failure" and "treatment refusal [MeSH]". In addition, the references of the identified literature were handsearched for further relevant literature. All the factors found in the literature were summarized in a mind map (please see supplement figure No. 1) [18]. Thereby six superordinate categories of factors potentially contributing to complexity of drug treatment (i.e. dosage forms, product characteristics, dosage schemes, additional instructions, patient characteristics and process characteristics) have emerged and the literature search was concluded when no further categories were found, because all factors identified could be assigned to one of them. An expert panel including VSW, SJS, AL and HMS discussed the relevance of each category, and, thus, these six categories were expected to cover all relevant factors that either directly increase complexity, such as drug and regimen-related aspects, or indirectly complexify drug treatment, such as characteristics of the medication process or of the patient himself. Conclusively, the six categories were confirmed by all authors as part of a workshop.
Based on the results of this introductory search, a non-systematic, purposeful search was performed in MEDLINE via Pubmed. As a starting point, the literature of the initial search and the references of the selected articles were searched. Additionally, search terms related to the defined six categories were used (please see supplement table No. 1) and combined with the search terms of the inductive search (please see above). The references of the identified literature as well as similar articles proposed by Pubmed were handsearched for further relevant factors. Literature found in the inductive search was also included in this literature search. Factors attributing to complexity were derived from studies and reviews that assessed drug handling and administration by adults in primary care (self-administration of drugs). In order to consider only relevant patient-level aspects, factors influencing complexity were included if administration errors, nonadherence or related adverse drug events were reported. If there were any indications in the literature of other factors that did not yet fulfill the inclusion criteria (e.g. no outpatient setting), MEDLINE was explicitly searched for this factor. Two researchers, VSW and SJS, worked on the six superordinate categories and reviewed each other's factors as well as the underlying sources before including them. In case of uncertainties of inclusion or exclusion of a complexity factor, a decision was sought in discussion between the two researchers and three pharmacists (AL, SB and HMS) with experience in adherence research. The literature search was finished when a saturation of information was reached and no further complexity factors were identified.

In addition, the validated and frequently used MRCI [4] was evaluated to identify further complexity factors related to the medication regimen.

\section{Results}

Ninety-one patient-centered influencing factors on the complexity of drug treatment were identified: fourteen relating to "dosage forms", five relating to "product characteristics", twelve relating to "dosage schemes", nine relating to "additional instructions", thirty-one relating to "patient characteristics" and twenty relating to "process characteristics". Seventeen of these factors were not identified in the initial search, but were found in the items of the MRCI [4]: four relating to "dosage forms", six relating to "dosage schemes" and seven relating to "additional instructions".

\section{Dosage forms}

Almost all dosage forms were described as predictive for administration errors or nonadherence in a specific context. The use of inhalers [19], injection devices [20-22], transdermal patches [23] and nasal preparations [24] and even 
of solid [25] or liquid [26] oral dosage forms was accompanied by administration errors. Furthermore, nonadherence was described for the use of ophthalmic preparations like eye drops [27], rectal preparations [28, 29] such as suppositories and enemas as well as dermatological preparations (Table 1) [30, 31].

\section{Product characteristics}

Similar drug names [33] and drug appearances [34, 35] led to administration errors as well as the patient-unfriendly nature of solid [25] or liquid oral drugs [36, 37]. Moreover, packaging that was difficult to open reduced adherence (Table 2) [37, 38].

\section{Dosage schemes}

An already frequently used measure for the complexity of drug treatment is the number of drugs concurrently used. For this type of complexity, the outcome on the part of the patient, namely nonadherence, has been frequently evaluated. Indeed, the risk of nonadherence increased with an increasing number of regularly used drugs [39-41]. Moreover, intake once a week [42], the number of daily intakes [28, 43, 44] and the number of drugs per intake [45] also influenced adherence. The timing of drug administration [46] and necessity of tablet splitting [47] was associated with a decrease in adherence (Table 3).

\section{Additional instructions}

For some medicines, additional instructions for correct use are necessary. Following these instructions can be difficult, so low adherence was observed when medicines had to be taken at fixed times of the day [50]. Similarly, nonadherence was caused by deviations from instructions, especially when drug intake depended on meals (Table 4) [51].

\section{Patient characteristics}

It is obvious that patients' characteristics may have an impact on drug use, i.e. visual impairment, cognitive decline or incomprehension may result in incorrect application or omission of administration, the latter measured as nonadherence. Sociodemographic characteristics like some age groups (younger than 65 years and older than 84 years) [53-55], not being partnered or married [56] or not having support in drug handling [47] and female sex [57] were related to nonadherence. Similarly, different levels of education (low as well as high levels of education) $[58,59]$, poor numeracy [60] and low health literacy [15] were associated with nonadherence. Moreover, unemployment [31] and the income of the patient (low-class and middle-class income) [61, 62] affected adherence negatively along with a busy lifestyle [28] and the use of alcohol [31] or illicit drugs [63].

Health-related conditions like cognitive $[61,64]$ and physical $[13,65]$ limitations, especially swallowing difficulties [25], were also associated with reduced adherence and administration errors.

Table 1 Drug dosage forms influencing the correct administration on the part of the patient

\begin{tabular}{|c|c|c|c|}
\hline Dosage form & Described effect & Description/Example & References \\
\hline Inhalers & Administration error & No breath holding or too slow inhalation & {$[19]$} \\
\hline Injection devices (non-prefilled) & Administration error & $\begin{array}{l}\text { No desinfection, air injection into vial or waiting } \\
\text { before needle removal }\end{array}$ & {$[20]$} \\
\hline Injection devices (prefilled) & Administration error & $\begin{array}{l}\text { Resuspending insulin incorrectly or no removal } \\
\text { of protection caps }\end{array}$ & {$[21,22]$} \\
\hline Transdermal patches & Administration error & $\begin{array}{l}\text { Choosing wrong administration site or no removal } \\
\text { of old patches }\end{array}$ & {$[23]$} \\
\hline Nasal preparations & Administration error & Overdosing by administring too many drops & {$[24]$} \\
\hline Solid oral dosage forms & Administration error & Intake with too little fluid or wrong tilt of head & {$[25]$} \\
\hline Liquid oral dosage forms & Administration error & $\begin{array}{l}\text { Over- or underdosing using different measurement } \\
\text { tools (syringe, cup, teaspoon) }\end{array}$ & {$[26]$} \\
\hline \multirow[t]{2}{*}{ Ophthalmic preparations } & Administration error & Touching the eye ball & {$[32]$} \\
\hline & Nonadherence & & {$[27]$} \\
\hline \multicolumn{4}{|c|}{ Dosage forms associated with nonadherence } \\
\hline Rectal preparations $[28,29]$ & & Dermatological preparations $[30,31]$ & \\
\hline \multicolumn{4}{|c|}{ Dosage forms extracted from MRCI [4] } \\
\hline $\begin{array}{l}\text { Solid dosage forms for } \\
\text { oropharyngeal use }\end{array}$ & $\begin{array}{l}\text { Liquid dosage forms for } \\
\text { oropharyngeal use }\end{array}$ & Otological preparations & Vaginal preparations \\
\hline
\end{tabular}


Table 2 Product characteristics of drugs and their packaging with impact on administration errors or adherence

\begin{tabular}{|c|c|c|c|}
\hline Characteristic & Described effect & Description/Example & References \\
\hline Similar drug names & $\begin{array}{l}\text { Administration } \\
\quad \text { error }\end{array}$ & Administration of wrong drug & {$[33]$} \\
\hline Similar drug appearance & $\begin{array}{l}\text { Administration } \\
\text { error }\end{array}$ & Administration of wrong drug & {$[34,35]$} \\
\hline $\begin{array}{l}\text { Patient-unfriendly nature of } \\
\text { solid oral dosage forms }\end{array}$ & $\begin{array}{l}\text { Administration } \\
\text { error }\end{array}$ & $\begin{array}{l}\text { Inappropriate modification of dosage form } \\
\text { due to form of tablets or surface material }\end{array}$ & {$[25]$} \\
\hline $\begin{array}{l}\text { Patient-unfriendly nature of } \\
\text { liquid oral dosage forms }\end{array}$ & $\begin{array}{l}\text { Administration } \\
\text { error }\end{array}$ & $\begin{array}{l}\text { Dosing error due to viscosity or modified } \\
\text { administration due to unpleasant flavor }\end{array}$ & {$[36,37]$} \\
\hline \multicolumn{4}{|c|}{ Product characteristics associated with nonadherence } \\
\hline \multicolumn{4}{|l|}{ Intricate packaging $[37,38]$} \\
\hline
\end{tabular}

Furthermore, a disease duration less than 10 years [58], an advanced disease [58], and the presence of comorbidities [39], in particular depression [16], contributed to nonadherence.

Patients' experiences with side effects [66] or a lack of symptom control [61] and low satisfaction with health care [67] had shown to affect adherence. Likewise, patients were more often nonadherent if they expressed concerns about drug treatment [39] or felt stigmatized by the disease [66]. Similarly, further attitudes like low acceptance of the disease [58] and a lack of interest in drug treatment [68] reduced adherence, as well as otherwise lacking knowledge of disease and drug treatment [61]. Additionally, the use of alternative medicines [69] and a negative attitude towards drug treatment in general [70] influenced adherence negatively (Table 5).

\section{Process characteristics}

Lack of training in dosage form use [19, 71], frequently changing prescriptions [72] or modifications of an existing medication regimen [5] led to more administration errors.
Moreover, filling a pill box, which is often used to organize medication was a complex task that was prone to errors [73]. A simpler language in patient information leaflets reduced administration errors compared with the common language standard [74]. In general, therapy instructions must be formulated in a comprehensible way and should not vary between different physicians [72].

In addition to factors leading to administration errors, other factors showed their influence on adherence behavior. Product changes like each new prescription [62], frequent generic substitutions [75] and changes in tablet color or shape increased the incidence for nonadherence [76]. Moreover, if patients received their medication from several pharmacies [77], consulted several prescribing physicians at the same time [77], were never treated by a specialist [55] or were discharged from hospital [78], they also were less adherent. Similarly, the adherence was reduced by the supply of small package sizes [79], high costs for patients [62] or drug therapies lasting longer than 5 years [66]. Furthermore, less frequent control visits [80] or complex measurements such as self-measured

Table 3 Dosage schemes resulting in administration errors and/or nonadherence

\begin{tabular}{|c|c|c|c|}
\hline Dosage scheme & Described effect & Description/Example & References \\
\hline \multirow[t]{2}{*}{ Once weekly administration } & Administration error & $\begin{array}{l}\text { Overdosing by using } \\
\text { every day }\end{array}$ & [42] \\
\hline & Nonadherence & & {$[48]$} \\
\hline \multirow[t]{2}{*}{ Tablet splitting } & Administration error & $\begin{array}{l}\text { Splitting despite missing } \\
\text { notches }\end{array}$ & [49] \\
\hline & Nonadherence & & {$[47]$} \\
\hline \multicolumn{4}{|c|}{ Dosage schemes associated with nonadherence } \\
\hline Total number of drugs [39-41] & $\begin{array}{l}\text { Administration more than } \\
\text { two times daily }[28,43,44]\end{array}$ & $\begin{array}{r}\text { More than one drug } \\
\text { concurrently [45] }\end{array}$ & $\begin{array}{l}\text { Administration at lunch } \\
\text { time [46] }\end{array}$ \\
\hline \multicolumn{4}{|c|}{ Dosage schemes extracted from MRCI [4] } \\
\hline Pro re nata (as needed) medication & $\begin{array}{l}\text { Administration every two } \\
\text { days or less frequently }\end{array}$ & Fixed dosing interval & $\begin{array}{l}\text { Use of multiple doses } \\
\text { concurrently }\end{array}$ \\
\hline $\begin{array}{l}\text { Different doses of the same active } \\
\text { ingredient at different times of day }\end{array}$ & Variable dosing & & \\
\hline
\end{tabular}


Table 4 Additional instructions increasing complexity of drug treatment

Instructions associated with nonadherence

Administration at fixed times of the day [50]

Instructions extracted from MRCI [4]

Increasing doses

Additional instructions

Decreasing doses
Crushing tablets
Meal-dependent administration [51, 52]

Disintegrating tablets, capsules and powders

Opening capsules

Intake with advised liquid

blood glucose concentrations were associated with intentional nonadherence [81]. Moreover, a lack of information about the disease and drug treatment [66] along with no use of a medication schedule [82] had a negative effect on adherence (Table 6).

\section{Discussion}

Many influencing factors have been found across all six predefined categories, supporting the assumption that the entire medication process contributes to complexity of drug treatment. However, the number of factors found in each category varies. This may be since there actually are fewer factors in some categories than in others or that the categories are studied to a different extent.

In order to be applicable, some of the factors identified require further specifications. For example, there is a known relationship between complexity of drug treatment and the total number of drugs used [39-41]. However, the number of drugs examined for nonadherence differs from study to study. A usual cut-off for this parameter is the daily use of five or more drugs, which is a common definition of polypharmacy, too [10]. For this number of drugs, a reduced adherence could be shown [83].

Furthermore, it must be kept in mind that all the complexity factors were mostly examined independently and were not compared with each other. Thus, the extent of the influence of individual factors in a specific patient cannot be determined, and it is not yet possible to predict sufficiently whether and to what extent different factors influence each other or not. Additionally, the underlying patient samples differ in many characteristics, e.g. age, morbidities or social environment, as well as the settings studied. Therefore, transferability to an individual patient level is limited, and the applicability in the respective setting should be verified.

Moreover, some of the complexity factors found only indirectly affect complexity of drug treatment. For instance, an

Table 5 Patient characteristics associated with incorrect administration of drugs and nonadherence

Patient characteristics associated with nonadherence

\section{Sociodemographic characteristics}

Younger than 65 years $[53,55]$

No support in drug handling [47]

High education level [59]

Unemployment [31]

Busy lifestyle [28]

Health-related conditions

Cognitive impairment [61, 64]

Disease duration less than ten years [58]

Depression [16]

\section{Experiences}

Experienced side effects [66]

Attitude towards disease/therapy

Concerns about drug treatment [39]

Lack of interest in drug treatment [68]

Use of alternative medicines [69]
Older than 84 years [54]

Female sex [57]

Poor numeracy skills [60]

Low income [61]

Alcohol or illicit drug use [31, 63]

Physical impairment [13, 65]

Advanced disease [58]

Lack of symptom control [61]

Feeling stigmatized by disease/drug treatment [66]

Lack of knowledge regarding disease/drug treatment [61]
Low satisfaction with health care [67]

No partner/spouse [56]

Low education level [58]

Low health literacy [15]

Middle-class income [62]

Swallowing difficulties [25]

One or more comorbidities [39]

Low acceptance of disease [58]

Negative attitude towards drug treatment [70] 
Table 6 Process characteristics resulting in administration errors or nonadherence

\begin{tabular}{|c|c|c|c|}
\hline Characteristic & Described effect & Description/Example & References \\
\hline Lack of training in dosage form use & Administration error & $\begin{array}{l}\text { No gentle exhalation before inhalation } \\
\text { or no breath holding }\end{array}$ & {$[19,71]$} \\
\hline Frequently changing prescriptions & Administration error & $\begin{array}{l}\text { Drug confusion or forgetting about how } \\
\text { to take drug }\end{array}$ & {$[72]$} \\
\hline Changes in existing medication regimen & Administration error & $\begin{array}{l}\text { Wrong reaction to physicians advice } \\
\text { or self-monitoring results }\end{array}$ & [5] \\
\hline Use of pill boxes & Administration error & Filling with wrong drug & {$[73]$} \\
\hline Difficult language in patient information leaflet & Administration error & $\begin{array}{l}\text { Wrong preparation and pen self-injection } \\
\text { technique }\end{array}$ & [74] \\
\hline $\begin{array}{l}\text { Lack of comprehensibility and transparency } \\
\text { of the instructions for drug treatment }\end{array}$ & Administration error & $\begin{array}{l}\text { Drug confusion or forgetting about how } \\
\text { to take drug }\end{array}$ & {$[72]$} \\
\hline \multicolumn{4}{|l|}{ Process characteristics associated with nonadherence } \\
\hline \multicolumn{4}{|l|}{ Product changes } \\
\hline New prescription [62] & Frequent generic substitution [75] & Changes in tablet color or shape [76] & \\
\hline \multicolumn{4}{|l|}{ Supply parameters } \\
\hline Large number of pharmacies [77] & $\begin{array}{l}\text { Large number of prescribing } \\
\text { physicians [77] }\end{array}$ & No treatment by specialists [55] & \\
\hline Hospital discharge [78] & Small package size supply [79] & High costs [62] & \\
\hline \multicolumn{4}{|l|}{ Drug treatment for more than five years [66] } \\
\hline \multicolumn{4}{|l|}{ Monitoring } \\
\hline Low frequency of control visits to the physician [80] & $\begin{array}{l}\text { Complex measurements } \\
\quad \text { (self-performed) [81] }\end{array}$ & & \\
\hline \multicolumn{4}{|l|}{ Information } \\
\hline $\begin{array}{l}\text { Lack of information about the disease/ drug } \\
\text { treatment [66] }\end{array}$ & $\begin{array}{l}\text { No use of medication schedule } \\
{[82]}\end{array}$ & & \\
\hline
\end{tabular}

association between age and adherence has already been shown, but it has to be considered that age as a complexity factor implies other factors such as the number of comorbidities and consequently the total number of drugs used [11]. Therefore, the relevance of each individual factor should be assessed before use.

Previous reviews concentrated on certain patients, e.g. with specific diseases $[84,85]$ or of older age $[86,87]$. Restricted to such conditions, these reviews may assess factors quantitatively, but their results need to be further summarized to provide an overview of all possible influencing factors. It should be noted that some factors were reported superficially, like "complex medication regimen" [84-86] without specifying what a complex medication regimen actually looked like. To assess reasons for complexity of drug treatment, these reviews therefore provide limited evidence. Furthermore, most of the reviews used adherence as the only outcome parameter [84-87]. However, administration errors show the problems of the patients with their medication as well. Reviews focusing on patients' administration errors reported little about their causes, indicating more generic circumstances such as low health literacy, cognitive impairment or poor communication as reasons [88]. In contrast to previous reviews, this work summarizes many of the factors influencing complexity of drug treatment without the restrictions mentioned and provides a comprehensive, patient-centered overview, assessing both administration errors and nonadherence. As a side effect, many items listed in the MRCI were confirmed by further literature supporting their relevance.

However, this literature search led to heterogeneous results regarding the characteristics of some factors. Factors such as solid oral dosage forms [25] show little informative value because their characteristics are formulated too generally. For age [53-55], level of education [58, 59] and income [61, $62]$, the literature even shows contradictory characteristics. Moreover, for some factors, even their influence on the individual patient generally remains unclear. For example, the attribute "additional instructions" has already reported to potentially increase complexity [4] as well as to improve adherence under certain circumstances [89]. An assessment, especially of ambiguous factors, seems reasonable before those are used to assess complexity.

This review has several limitations; in particular, several methodological issues must be considered. First, the six categories of complexity factors were defined based on an unstructured literature search and an expert panel. Consequently, neither a structured literature search nor a formal consensus technique was applied. Nevertheless, all 
the complexity factors found could be applied to one of the categories, suggesting that they comprehensively cover all aspects of complexity of drug treatment. Second, MEDLINE was the only literature database that was searched, both for the introductory search leading to the definition of the categories and for the further literature search to identify complexity factors. Thus, relevant results, i.e. complexity factors, may be missed as other databases, such as CINAHL or PsycINFO, may refer to further factors and, accordingly, even further categories. However, the search in MEDLINE already led to a large number of relevant literature, thus leading to a large number of complexity factors. Moreover, saturation of information was observed during literature search.

\section{Conclusion}

To the best of our knowledge, this review is the first, most comprehensive work of its kind. It demonstrates that complexity of drug treatment is not based exclusively on the medication regimen and suggests that multiple complexity factors must be considered when analyzing complexity of drug treatment. Based on these results, the patients' perspective on the complexity factors must be examined to understand the reasons for the emergence of complexity of drug treatment and, thus, develop targeted measures to simplify drug treatment. In future projects, algorithms will be developed to consider all these complexity factors when analyzing complexity of drug treatment (Project HIOPP-6 [90]). Only if complexity of drug treatment can be assessed in a standardized way for the individual patient, tailored measures can be found to simplify drug treatment for the patient.

Acknowledgments Open access funding was provided by projekt DEAL. The HIOPP-6 consortium consists of the following partners: Stefan Wilm, Achim Mortsiefer, Institute of General Practice, HeinrichHeine University Düsseldorf, Moorenstraße 5, 40227 Düsseldorf, Germany; Attila Altiner, Lisa Sparenberg, Institute of General Practice, Rostock University Medical Center, Doberaner Straße 142, 18057 Rostock, Germany; Joachim Szecsenyi, Frank Peters-Klimm, Department of General Practice and Health Services Research, Heidelberg University Hospital, Im Neuenheimer Feld 130.3, 69120 Heidelberg, Germany; Petra Kaufmann-Kolle, AQUA-Institute for Applied Quality Improvement and Research in Health Care, Maschmühlenweg 8-10, 37073 Göttingen, Germany.

Author contribution S. J. Schmidt contributed to the review design, selected the studies, extracted and assessed the data and drafted the manuscript. V. S. Wurmbach contributed to the review design, selected the studies, extracted and assessed the data and drafted the review. A. Lampert planned and designed the review, advised in data assessment process and revised the draft critically. S. Bernard contributed to the review design, advised in data assessment process and revised the draft critically. The HIOPP- 6 Consortium contributed to the review design and revised the draft critically. W. E. Haefeli planned and designed the review and revised the draft critically. H. M. Seidling planned and designed the review, advised in data assessment process and revised the draft critically. P. A. Thürmann planned and designed the review, advised in data assessment process and revised the draft critically. All authors were responsible for the final approval of the version to be published.

Funding information This work was supported by the Innovation Fund of The Federal Joint Committee under Grant number 01VSF16019.

\section{Compliance with ethical standards}

Disclosure of potential conflicts of interest The authors declare that they have no conflict of interest with regard to this work. Moreover, all potential conflicts of interests are documented in the respective ICMJE forms.

Open Access This article is licensed under a Creative Commons Attribution 4.0 International License, which permits use, sharing, adaptation, distribution and reproduction in any medium or format, as long as you give appropriate credit to the original author(s) and the source, provide a link to the Creative Commons licence, and indicate if changes were made. The images or other third party material in this article are included in the article's Creative Commons licence, unless indicated otherwise in a credit line to the material. If material is not included in the article's Creative Commons licence and your intended use is not permitted by statutory regulation or exceeds the permitted use, you will need to obtain permission directly from the copyright holder. To view a copy of this licence, visit http://creativecommons.org/licenses/by/4.0/.

\section{References}

1. Muir AJ, Sanders LL, Wilkinson WE, Schmader K (2001) Reducing medication regimen complexity: a controlled trial. J Gen Intern Med 16(2):77-82

2. Lindquist LA, Lindquist LM, Zickuhr L, Friesema E, Wolf MS (2014) Unnecessary complexity of home medication regimens among seniors. Patient Educ Couns 96(1):93-97. https://doi.org/ 10.1016/j.pec.2014.03.022

3. Pantuzza LL, Ceccato M, Silveira MR, Junqueira LMR, Reis AMM (2017) Association between medication regimen complexity and pharmacotherapy adherence: a systematic review. Eur J Clin Pharmacol 73(11):1475-1489. https://doi.org/10.1007/s00228017-2315-2

4. George J, Phun YT, Bailey MJ, Kong DC, Stewart K (2004) Development and validation of the medication regimen complexity index. Ann Pharmacother 38(9):1369-1376. https://doi.org/10. 1345/aph.1D479

5. Field TS, Mazor KM, Briesacher B, Debellis KR, Gurwitz JH (2007) Adverse drug events resulting from patient errors in older adults. J Am Geriatr Soc 55(2):271-276. https://doi.org/10.1111/j. 1532-5415.2007.01047.x

6. Barat I, Andreasen F, Damsgaard EM (2001) Drug therapy in the elderly: what doctors believe and patients actually do. Br J Clin Pharmacol 51(6):615-622

7. Sokol MC, McGuigan KA, Verbrugge RR, Epstein RS (2005) Impact of medication adherence on hospitalization risk and healthcare cost. Med Care 43(6):521-530

8. Simpson SH, Eurich DT, Majumdar SR, Padwal RS, Tsuyuki RT, Varney J, Johnson JA (2006) A meta-analysis of the association between adherence to drug therapy and mortality. Bmj 333(7557): 15. https://doi.org/10.1136/bmj.38875.675486.55 
9. Brysch EG, Cauthon KAB, Kalich BA, Sarbacker GB (2018) Medication regimen complexity index in the elderly in an outpatient setting: a literature review. Consult Pharm 33(9):484-496. https://doi.org/10.4140/TCP.n.2018.484

10. Masnoon N, Shakib S, Kalisch-Ellett L, Caughey GE (2017) What is polypharmacy? A systematic review of definitions. BMC Geriatr 17(1):230. https://doi.org/10.1186/s12877-017-0621-2

11. Knopf H, Grams D (2013) Medication use of adults in Germany: results of the German health interview and examination survey for adults (DEGS1). Bundesgesundheitsbl Gesundheitsforsch Gesundheitsschutz 56(5-6):868-877. https://doi.org/10.1007/ s00103-013-1667-8

12. Qato DM, Wilder J, Schumm LP, Gillet V, Alexander GC (2016) Changes in prescription and over-the-counter medication and dietary supplement use among older adults in the United States, 2005 vs 2011. JAMA Intern Med 176(4):473-482. https://doi.org/10. 1001/jamainternmed.2015.8581

13. Winfield AJ, Jessiman D, Williams A, Esakowitz L (1990) A study of the causes of non-compliance by patients prescribed eyedrops. Br J Ophthalmol 74(8):477-480

14. Chang WT, Kowalski SR, Sorich W, Alderman CP (2017) Medication regimen complexity and prevalence of potentially inappropriate medicines in older patients after hospitalisation. Int $\mathrm{J}$ Clin Pharm 39(4):867-873. https://doi.org/10.1007/s11096-0170490-y

15. Zhang NJ, Terry A, McHorney CA (2014) Impact of health literacy on medication adherence: a systematic review and meta-analysis. Ann Pharmacother 48(6):741-751. https://doi.org/10.1177/ 1060028014526562

16. DiMatteo MR, Lepper HS, Croghan TW (2000) Depression is a risk factor for noncompliance with medical treatment: meta-analysis of the effects of anxiety and depression on patient adherence. Arch Intern Med 160(14):2101-2107

17. Paquin AM, Zimmerman KM, Kostas TR, Pelletier L, Hwang A, Simone M, Skarf LM, Rudolph JL (2013) Complexity perplexity: a systematic review to describe the measurement of medication regimen complexity. Expert Opin Drug Saf 12(6):829-840. https://doi. org/10.1517/14740338.2013.823944

18. Buzan T, Buzan B (1993) The mind map book. BBC Books, London

19. Arora P, Kumar L, Vohra V, Sarin R, Jaiswal A, Puri MM, Rathee D, Chakraborty P (2014) Evaluating the technique of using inhalation device in COPD and bronchial asthma patients. Respir Med 108(7):992-998. https://doi.org/10.1016/j.rmed.2014.04.021

20. Stacciarini TS, Pace AE, Haas VJ (2009) Insulin self-administration technique with disposable syringe among patients with diabetes mellitus followed by the family health strategy. Rev Lat Am Enfermagem 17(4):474-480

21. Brown A, Steel JM, Duncan C, Duncan A, McBain AM (2004) An assessment of the adequacy of suspension of insulin in pen injectors. Diabet Med 21(6):604-608. https://doi.org/10.1111/j.14645491.2004.01206.x

22. Truong TH, Nguyen TT, Armor BL, Farley JR (2017) Errors in the administration technique of insulin pen devices: a result of insufficient education. Diabetes Ther 8(2):221-226. https://doi.org/10. 1007/s13300-017-0242-y

23. Lampert A, Seiberth J, Haefeli WE, Seidling HM (2014) A systematic review of medication administration errors with transdermal patches. Expert Opin Drug Saf 13(8):1101-1114. https://doi.org/ 10.1517/14740338.2014.926888

24. Patel RS, McGarry GW (2001) Most patients overdose on topical nasal corticosteroid drops: an accurate delivery device is required. $\mathrm{J}$ Laryngol Otol 115(8):633-635

25. Schiele JT, Quinzler R, Klimm HD, Pruszydlo MG, Haefeli WE (2013) Difficulties swallowing solid oral dosage forms in a general practice population: prevalence, causes, and relationship to dosage forms. Eur J Clin Pharmacol 69(4):937-948. https://doi.org/10. 1007/s00228-012-1417-0

26. Yin HS, Parker RM, Sanders LM, Dreyer BP, Mendelsohn AL, Bailey S, Patel DA, Jimenez JJ, Kim KA, Jacobson K, Hedlund L, Smith MC, Maness Harris L, McFadden T, Wolf MS (2016) Liquid medication errors and dosing tools: a randomized controlled experiment. Pediatrics 138(4). https://doi.org/10.1542/peds.20160357

27. Norell SE, Granstrom PA (1980) Self-medication with pilocarpine among outpatients in a glaucoma clinic. Br J Ophthalmol 64(2): 137-141

28. Boyle M, Ting A, Cury DB, Nanda K, Cheifetz AS, Moss A (2015) Adherence to rectal mesalamine in patients with ulcerative colitis. Inflamm Bowel Dis 21(12):2873-2878. https://doi.org/10.1097/ mib.0000000000000562

29. D'Inca R, Bertomoro P, Mazzocco K, Vettorato MG, Rumiati R, Sturniolo GC (2008) Risk factors for non-adherence to medication in inflammatory bowel disease patients. Aliment Pharmacol Ther 27(2):166-172. https://doi.org/10.1111/j.1365-2036.2007.03555.x

30. Saeki H, Imafuku S, Abe M, Shintani Y, Onozuka D, Hagihara A, Katoh N, Murota H, Takeuchi S, Sugaya M, Tanioka M, Kaneko S, Masuda K, Hiragun T, Inomata N, Kitami Y, Tsunemi Y, Abe S, Kobayashi M, Morisky DE, Furue M (2015) Poor adherence to medication as assessed by the Morisky Medication Adherence Scale- 8 and low satisfaction with treatment in 237 psoriasis patients. J Dermatol 42(4):367-372. https://doi.org/10.1111/13468138.12804

31. Murota H, Takeuchi S, Sugaya M, Tanioka M, Onozuka D, Hagihara A, Saeki H, Imafuku S, Abe M, Shintani Y, Kaneko S, Masuda K, Hiragun T, Inomata N, Kitami Y, Tsunemi Y, Abe S, Kobayashi M, Morisky DE, Furue M, Katoh N (2015) Characterization of socioeconomic status of Japanese patients with atopic dermatitis showing poor medical adherence and reasons for drug discontinuation. J Dermatol Sci 79(3):279-287. https://doi. org/10.1016/j.jdermsci.2015.05.010

32. Ikeda H, Tsukamoto H, Sugimoto A, Sawa A, Crabtree BL, Byrd HJ, Murakami T, Mishima HK, Kihira K (2008) Clinical significance of topical instillation technique in Japanese glaucoma patients. Pharmazie 63(1):81-85

33. Ciociano N, Bagnasco L (2014) Look alike/sound alike drugs: a literature review on causes and solutions. Int J Clin Pharm 36(2): 233-242. https://doi.org/10.1007/s11096-013-9885-6

34. Tranchard F, Hein C, Lacombe J, Villars H, Montastruc JL, Despas F (2016) Medication errors and look-alike tablets: the splitting issue. Pharmacoepidemiol Drug Saf 25(9):1002-1003. https://doi. org $/ 10.1002 /$ pds. 4063

35. Lavon O, Ben-Zeev A, Bentur Y (2014) Medication errors outside healthcare facilities: a national poison centre perspective. Basic Clin Pharmacol Toxicol 114(3):288-292. https://doi.org/10.1111/bcpt. 12150

36. Peacock G, Parnapy S, Raynor S, Wetmore S (2010) Accuracy and precision of manufacturer-supplied liquid medication administration devices before and after patient education. J Am Pharm Assoc (2003) 50(1):84-86. https://doi.org/10.1331/JAPhA.2010. 09006

37. Notenboom K, Leufkens HG, Vromans H, Bouvy ML (2017) Learning from patients: identifying design features of medicines that cause medication use problems. Int J Pharm 517(1-2):128134. https://doi.org/10.1016/j.ijpharm.2016.12.004

38. Sirey JA, Greenfield A, Weinberger MI, Bruce ML (2013) Medication beliefs and self-reported adherence among community-dwelling older adults. Clin Ther 35(2):153-160. https://doi.org/10.1016/j.clinthera.2013.01.001

39. Jarab AS, Almrayat R, Alqudah S, Thehairat E, Mukattash TL, Khdour M, Pinto S (2014) Predictors of non-adherence to 
pharmacotherapy in patients with type 2 diabetes. Int J Clin Pharm 36(4):725-733. https://doi.org/10.1007/s11096-014-9938-5

40. Gray SL, Mahoney JE, Blough DK (2001) Medication adherence in elderly patients receiving home health services following hospital discharge. Ann Pharmacother 35(5):539-545. https://doi.org/10. 1345/aph.10295

41. Grosset KA, Bone I, Grosset DG (2005) Suboptimal medication adherence in Parkinson's disease. Mov Disord 20(11):1502-1507. https://doi.org/10.1002/mds.20602

42. Guanabens N, Monegal A, Cerda D, Muxi A, Gifre L, Peris P, Pares A (2013) Randomized trial comparing monthly ibandronate and weekly alendronate for osteoporosis in patients with primary biliary cirrhosis. Hepatology 58(6):2070-2078. https://doi.org/10.1002/ hep. 26466

43. Paes AH, Bakker A, Soe-Agnie CJ (1997) Impact of dosage frequency on patient compliance. Diabetes Care 20(10):1512-1517

44. Llor C, Bayona C, Hernandez S, Moragas A, Miravitlles M (2012) Comparison of adherence between twice- and thrice-daily regimens of oral amoxicillin/clavulanic acid. Respirology 17(4):687-692. https://doi.org/10.1111/j.1440-1843.2012.02159.x

45. Sherrill B, Halpern M, Khan S, Zhang J, Panjabi S (2011) Singlepill vs free-equivalent combination therapies for hypertension: a meta-analysis of health care costs and adherence. J Clin Hypertens (Greenwich) 13(12):898-909. https://doi.org/10.1111/j. 1751-7176.2011.00550.x

46. Martin-Latry K, Cazaux J, Lafitte M, Couffinhal T (2014) Negative impact of physician prescribed drug dosing schedule requirements on patient adherence to cardiovascular drugs. Pharmacoepidemiol Drug Saf 23(10):1088-1092. https://doi.org/10.1002/pds.3608

47. Lam PW, Lum CM, Leung MF (2007) Drug non-adherence and associated risk factors among Chinese geriatric patients in Hong Kong. Hong Kong Med J 13(4):284-292

48. Moore TJ, Walsh CS, Cohen MR (2004) Reported medication errors associated with methotrexate. Am J Health Syst Pharm 61(13): $1380-1384$

49. Quinzler R, Gasse C, Schneider A, Kaufmann-Kolle P, Szecsenyi J, Haefeli WE (2006) The frequency of inappropriate tablet splitting in primary care. Eur J Clin Pharmacol 62(12):1065-1073. https:// doi.org/10.1007/s00228-006-0202-3

50. Gill CJ, Sabin LL, Hamer DH, Keyi X, Jianbo Z, Li T, Wu WJ, Wilson IB, Desilva MB (2010) Importance of dose timing to achieving undetectable viral loads. AIDS Behav 14(4):785-793. https://doi.org/10.1007/s10461-009-9555-9

51. Fransen GA, Mesters I, Muris JW, Van Marrewijk CJ, Mujakovic S, Laheij RJ, Numans ME, de Wit NJ, Samsom M, Jansen JB, Knottnerus JA (2012) Patient adherence to prescribed medication instructions for dyspepsia: the DIAMOND-study. Eur J Gen Pract 18(2):79-85. https://doi.org/10.3109/13814788.2012.665443

52. Freigofas J, Haefeli WE, Schottker B, Brenner H, Quinzler R (2014) Indirect evidence for proton pump inhibitor failure in patients taking them independent of meals. Pharmacoepidemiol Drug Saf 23(7):768-772. https://doi.org/10.1002/pds.3620

53. Curtin RB, Svarstad BL, Andress D, Keller T, Sacksteder P (1997) Differences in older versus younger hemodialysis patients' noncompliance with oral medications. Geriatr Nephrol Urol 7(1):35-44

54. Chapman RH, Petrilla AA, Benner JS, Schwartz JS, Tang SS (2008) Predictors of adherence to concomitant antihypertensive and lipid-lowering medications in older adults: a retrospective, cohort study. Drugs Aging 25(10):885-892

55. Yen L, Wu J, Hodgkins PL, Cohen RD, Nichol MB (2012) Medication use patterns and predictors of nonpersistence and nonadherence with oral 5-aminosalicylic acid therapy in patients with ulcerative colitis. J Manag Care Pharm 18(9):701-712. https:// doi.org/10.18553/jmcp.2012.18.9.701

56. Berry DL, Blonquist TM, Hong F, Halpenny B, Partridge AH (2015) Self-reported adherence to oral cancer therapy: relationships with symptom distress, depression, and personal characteristics. Patient Prefer Adherence 9:1587-1592. https://doi.org/10.2147/ ppa.S91534

57. Manteuffel M, Williams S, Chen W, Verbrugge RR, Pittman DG, Steinkellner A (2014) Influence of patient sex and gender on medication use, adherence, and prescribing alignment with guidelines. J Women's Health (Larchmt) 23(2):112-119. https://doi.org/10.1089/ jwh.2012.3972

58. Jankowska-Polańska B, Chudiak A, Uchmanowicz I, Dudek K, Mazur G (2017) Selected factors affecting adherence in the pharmacological treatment of arterial hypertension. Patient Prefer Adherence 11:363-371. https://doi.org/10.2147/ppa.S127407

59. Tan C, Teng GG, Chong KJ, Cheung PP, Lim A, Wee HL, Santosa A (2016) Utility of the Morisky Medication Adherence Scale in gout: a prospective study. Patient Prefer Adherence 10:24492457. https://doi.org/10.2147/ppa.S119719

60. Apter AJ, Wan F, Reisine S, Bender B, Rand C, Bogen DK, Bennett IM, Bryant-Stephens T, Roy J, Gonzalez R, Priolo C, Have TT, Morales KH (2013) The association of health literacy with adherence and outcomes in moderate-severe asthma. J Allergy Clin Immunol 132(2):321-327. https://doi.org/10.1016/j.jaci.2013.02. 014

61. Valldeoriola F, Coronell C, Pont C, Buongiorno MT, Camara A, Gaig C, Compta Y (2011) Socio-demographic and clinical factors influencing the adherence to treatment in Parkinson's disease: the ADHESON study. Eur J Neurol 18(7):980-987. https://doi.org/10. 1111/j.1468-1331.2010.03320.x

62. Kirkman MS, Rowan-Martin MT, Levin R, Fonseca VA, Schmittdiel JA, Herman WH, Aubert RE (2015) Determinants of adherence to diabetes medications: findings from a large pharmacy claims database. Diabetes Care 38(4):604-609. https://doi.org/10. 2337/dc14-2098

63. Hermanstyne KA, Santos GM, Vittinghoff E, Santos D, Colfax G, Coffin P (2014) Event-level relationship between methamphetamine use significantly associated with non-adherence to pharmacologic trial medications in event-level analyses. Drug Alcohol Depend 143:277-280. https://doi.org/10.1016/j.drugalcdep.2014. 07.031

64. Smith D, Lovell J, Weller C, Kennedy B, Winbolt M, Young C, Ibrahim J (2017) A systematic review of medication non-adherence in persons with dementia or cognitive impairment. PLoS One 12(2): e0170651. https://doi.org/10.1371/journal.pone.0170651

65. Turner A, Hochschild A, Burnett J, Zulfiqar A, Dyer CB (2012) High prevalence of medication non-adherence in a sample of community-dwelling older adults with adult protective servicesvalidated self-neglect. Drugs Aging 29(9):741-749. https://doi. org/10.1007/s40266-012-0007-2

66. Getnet A, Woldeyohannes SM, Bekana L, Mekonen T, Fekadu W, Menberu M, Yimer S, Assaye A, Belete A, Belete H (2016) Antiepileptic drug nonadherence and its predictors among people with epilepsy. Behav Neurol 2016:3189108. https://doi.org/10. 1155/2016/3189108

67. Morisky DE, Ang A, Krousel-Wood M, Ward HJ (2008) Predictive validity of a medication adherence measure in an outpatient setting. J Clin Hypertens (Greenwich) 10(5):348-354

68. Efficace F, Baccarani M, Rosti G, Cottone F, Castagnetti F, Breccia M, Alimena G, Iurlo A, Rossi AR, Pardini S, Gherlinzoni F, Salvucci M, Tiribelli M, Vignetti M, Mandelli F (2012) Investigating factors associated with adherence behaviour in patients with chronic myeloid leukemia: an observational patientcentered outcome study. Br J Cancer 107(6):904-909. https://doi. org $/ 10.1038 /$ bjc. 2012.348

69. Roy A, Lurslurchachai L, Halm EA, Li XM, Leventhal H, Wisnivesky JP (2010) Use of herbal remedies and adherence to inhaled corticosteroids among inner-city asthmatic patients. Ann 
Allergy Asthma Immunol 104(2):132-138. https://doi.org/10. 1016/j.anai.2009.11.024

70. Bardel A, Wallander MA, Svardsudd K (2007) Factors associated with adherence to drug therapy: a population-based study. Eur J Clin Pharmacol 63(3):307-314. https://doi.org/10.1007/s00228006-0246-4

71. Poudel RS, Piryani RM, Shrestha S, Prajapati A (2017) Benefit of hospital pharmacy intervention on the current status of dry powder inhaler technique in patients with asthma and COPD: a study from the Central Development Region, Nepal. Integr Pharm Res Pract 6: 7-13. https://doi.org/10.2147/iprp.S119202

72. Mira JJ, Orozco-Beltran D, Perez-Jover V, Martinez-Jimeno L, GilGuillen VF, Carratala-Munuera C, Sanchez-Molla M, PertusaMartinez S, Asencio-Aznar A (2013) Physician patient communication failure facilitates medication errors in older polymedicated patients with multiple comorbidities. Fam Pract 30(1):56-63. https://doi.org/10.1093/fampra/cms046

73. Coumans C, Vandenberghe M, Fery P (2017) High rate of errors in pillbox filling by cognitively healthy elderly people. Geriatr Psychol Neuropsychiatr Vieil 15(3):273-282. https://doi.org/10. 1684/pnv.2017.0679

74. Smith MY, Wallace LS (2013) Reducing drug self-injection errors: a randomized trial comparing a "standard" versus "plain language" version of Patient Instructions for Use. Res Soc Adm Pharm 9(5): 621-625. https://doi.org/10.1016/j.sapharm.2012.10.007

75. Colombo GL, Agabiti-Rosei E, Margonato A, Mencacci C, Montecucco CM, Trevisan R, Catapano AL (2016) Impact of substitution among generic drugs on persistence and adherence: a retrospective claims data study from 2 Local Healthcare Units in the Lombardy Region of Italy. Atheroscler Suppl 21:1-8. https://doi. org/10.1016/j.atherosclerosissup.2016.02.001

76. Kesselheim AS, Bykov K, Avorn J, Tong A, Doherty M, Choudhry NK (2014) Burden of changes in pill appearance for patients receiving generic cardiovascular medications after myocardial infarction: cohort and nested case-control studies. Ann Intern Med 161(2):96103. https://doi.org/10.7326/m13-2381

77. Choudhry NK, Fischer MA, Avorn J, Liberman JN, Schneeweiss S, Pakes J, Brennan TA, Shrank WH (2011) The implications of therapeutic complexity on adherence to cardiovascular medications. Arch Intern Med 171(9):814-822

78. Mulhem E, Lick D, Varughese J, Barton E, Ripley T, Haveman J (2013) Adherence to medications after hospital discharge in the elderly. Int J Fam Med 2013:901845. https://doi.org/10.1155/ 2013/901845

79. Kazerooni R, Takizawa A, Vu K (2014) Predictors of adherence to hormonal contraceptives in a female veteran population. Contraception 89(4):292-298. https://doi.org/10.1016/j. contraception.2013.12.009

80. Patel NC, Crismon ML, Miller AL, Johnsrud MT (2005) Drug adherence: effects of decreased visit frequency on adherence to clozapine therapy. Pharmacotherapy 25(9):1242-1247. https://doi. org/10.1592/phco.2005.25.9.1242
81. de Vries ST, Keers JC, Visser R, de Zeeuw D, Haaijer-Ruskamp FM, Voorham J, Denig P (2014) Medication beliefs, treatment complexity, and non-adherence to different drug classes in patients with type 2 diabetes. J Psychosom Res 76(2):134-138. https://doi.org/ 10.1016/j.jpsychores.2013.11.003

82. Okuno J, Yanagi H, Tomura S (2001) Is cognitive impairment a risk factor for poor compliance among Japanese elderly in the community? Eur J Clin Pharmacol 57(8):589-594

83. Stoehr GP, Lu SY, Lavery L, Bilt JV, Saxton JA, Chang CC, Ganguli M (2008) Factors associated with adherence to medication regimens in older primary care patients: the Steel Valley Seniors Survey. Am J Geriatr Pharmacother 6(5):255-263. https://doi.org/ 10.1016/j.amjopharm.2008.11.001

84. Yeam CT, Chia S, Tan HCC, Kwan YH, Fong W, Seng JJB (2018) A systematic review of factors affecting medication adherence among patients with osteoporosis. Osteoporos Int 29(12):26232637. https://doi.org/10.1007/s00198-018-4759-3

85. van der Laan DM, Elders PJM, Boons C, Beckeringh JJ, Nijpels G, Hugtenburg JG (2017) Factors associated with antihypertensive medication non-adherence: a systematic review. J Hum Hypertens 31(11):687-694. https://doi.org/10.1038/jhh.2017.48

86. Yap AF, Thirumoorthy T, Kwan YH (2016) Systematic review of the barriers affecting medication adherence in older adults. Geriatr Gerontol Int 16(10):1093-1101. https://doi.org/10.1111/ggi.12616

87. Gellad WF, Grenard JL, Marcum ZA (2011) A systematic review of barriers to medication adherence in the elderly: looking beyond cost and regimen complexity. Am J Geriatr Pharmacother 9(1):11-23. https://doi.org/10.1016/j.amjopharm.2011.02.004

88. Mira JJ, Lorenzo S, Guilabert M, Navarro I, Perez-Jover V (2015) A systematic review of patient medication error on selfadministering medication at home. Expert Opin Drug Saf 14(6): 815-838. https://doi.org/10.1517/14740338.2015.1026326

89. George J, Vuong T, Bailey MJ, Kong DC, Marriott JL, Stewart K (2006) Medication regimen complexity and adherence in patients at risk of medication misadventure. J Pharm Pract Res 36(2):99-102. https://doi.org/10.1002/j.2055-2335.2006.tb00580.x

90. Haefeli WE (2017) HIOPP-6 - Projekt aus dem HIOPP Forschungsverbund: Hausärztliche Initiative zur Optimierung der Patientensicherheit bei Polypharmazie - Komplexitätsreduktion in der Polypharmazie unter Beachtung von Patientenpräferenzen. Innovationsausschuss beim Gemeinsamen Bundesausschuss. https://innovationsfonds.g-ba.de/projekte/versorgungsforschung/ hiopp-6-projekt-aus-dem-hiopp-forschungsverbundhausaerztliche-initiative-zur-optimierung-der-patientensicherheitbei-polypharmazie-komplexitaetsreduktion-in-der-polypharmazieunter-beachtung-von-patientenpraeferenzen.19. Accessed 22.09. 2019

Publisher's note Springer Nature remains neutral with regard to jurisdictional claims in published maps and institutional affiliations. 